B 203

\title{
電子回路基盤の赤外線可視化画像モーダルウェーブレット解析
}

\author{
臼田 優○, 早野 誠治, 齋藤 兆古（法政大学大学院）
}

堀井 清之（白百合女子大）

\section{Modal Wavelets Analysis of the Infrared Electronic Circuit Boards Images}

\author{
Yu Usuda, Seiji Hayano, Yoshifuru Saito and Kiyoshi Horii
}

\begin{abstract}
Modern microelectronics has made it possible to work out a lot of many small electronics, such as electronic calculator, radio, notebook computer and so on. As a result, electronics circuits have become small integrated circuits. This means that precise micron level inspecting technique should be exploited to produce the highly reliable electronics products.

In this paper, we apply the thermal infrared dynamic image method to the electronic circuit boards inspection. Our infrared dynamic image method plans to work out the extraction of fault parts from dynamic infrared image by applying modal wavelets transform. As a first step of this project, this paper demonstrates the usefulness of dynamic infrared image method to the nondestructive inspection of electronic printed circuit boards.
\end{abstract}

Keywords: Dynamic Infrared Image, Printed Circuit Boards, Nondestructive Inspection

\section{1. 緒 論}

映像情報による診断は医学などで見られるように, 極 めて具体的な現実の状態把握を可能する.たとえ言語が 異なる民族ですら, 映像情報で意志伝達を行えば誤解無 く伝わる.このように人間の視覚情報処理は全地球人類 共通の強力な知的機能である.

医学での可視化技術はX線から始まり核磁気共鳴を利 用したMRI 画像まで診断の強力な道具である. 工学・物 理学では, 電子影微鏡やX 線結晶構造解析法が発明され, その結果, 材料中の物理現象に関寸る因果関係解明に大 きな役割を果たしてきている.また, 製造業でも商品の品 質管理・品質保証のため赤外線カメラを用いた非破壊検 查の技術が実用化されている.

エレクトロニクス技術, 特に半導体技術では, 第 2 次大 戦後, ベル研のゲルマニウム接触型トランジスタやウェ スタンエレクトリック社の電界効果トランジスタなどが 開発され,この半導体技術の大幅な進歩により,パーソナ ルコンピュータや携带電話などの精密機器だけでなく， 冷蔵庫や炊飯器などの家電製品にもマイクロコンピュー ターを搭載した電子回路を組み込み可能とした。その結 果として, 電子機器の小型・軽量·高性能化がなされたが, これは電気・電子回路の高集積化を意味し, 事実上, 故障 時における故障䇢所の特定を不可能にしているのが現状 である ${ }^{4}$.
限られた地球凟源の有効活用が叫ばれる今日，極めて 広範に普及している電子機器の故障診断と修復技術は環 境工学の基幹技術と言える.

このような社会的背景に鑑み, 筆者らは極めて精緻に 作られたプリント基板回路を非浸襲的・非破壊的に検查 する方法を検討してきた. 電子回路の故障や久損部分を 特定する方法は電子機器の駆動中における周辺電磁界分 布を可視化する方法が最適と考える.これは，電子機器を 駆動することで動作の健全性が評価され，逆に異常な動 作をする場合, 可視化された周辺電磁界分布から回路の 故障部位の特定が原理的に可能であるためである.

近傍電磁界測定による電子機器の健全性評洒や故障診 断は原理的には有望であるが現実には実現が遅れている。 この理由滋界や電界ベクトル,すなわち, 電磁界の測定 技術が末成熟な点にある。ささらに電磁界ベクトルは周辺 電磁ノイズに弱い本質的な問題点もある.このような問 題点を解決する手段として, 電子機器を構成する電子回 路そのものに流れる電流や電圧分布を直接可視化するこ とを考える

電子回路中の電流や電圧は電子回路中にしか存在しな いとする拘束条件が有るにも拘らず,それぞれを独立に 可視化することは簡単な装置では難しい.このため, 電流 と電圧の内積である電力を可視化することを考える.当 然,電力も值接可視化は出来ないが, 熱分布として間接的 
に赤外線を用いて可視化可能である ${ }^{5)}$. 本稿では, フィル ム変圧器用いた $\mathrm{DC} / \mathrm{DC}$ コンバータの赤外線画像を撮影し, この赤外線画像が可視化電力分布画像として非破壊検査 に有効であるかを吟味する。

\section{2. 電子機器の赤外線可視化画像診断}

\section{1 赤外線カメラ}

赤外線カメラは非接触の温度測定法として従来の接触 式温度計にはなかった種々の優れた特性を持っているた め,特に電力設備の加熱監視炉,プラント設備の異常熱源 検知,工場排水管理など保安・省エネルギーでの利用のほ か,電気・電子機器,部品検査などにも有効に利用されて いる.

これら従来の利用法は対象物が持つ表面温度分布をそ のままの状態でとらえるため対象物に温度差がないよう な場合には,赤外線カメラが有効に活用できず,利用範囲 には自ら限界がある.しかし,近年の小型軽量電子機器は 印刷技術を用いたプリント基板からなり,発熱源である 電力が薄膜面上に分布するため,赤外線カメラは回路の 健全性を機器が動作中に直接監視可能と考えられる。

2.2 供試電子回路

小型軽量電子機器は必ず機器の動作に必要なエネルギ 一を供給する電源部分と信号の流れを司る信号回路から なる.電子機器の小型化で最大の問題は電源部分にあり, 特に磁気エネルギーを蓄積するトランスやリアクトルの 小型軽量化が難しい.トランスやリアクトルの小型化を 行う一方法は電源部の高周波化であり,高周波特性の良 いアモルファス磁性体の普及とともにかなりの小型化が 推進された。

本稿では,供試電子回路として最も構造が簡単なフラ イバック型 $\mathrm{DC} / \mathrm{DC}$ コンバータを取り上げる.このコンバ ータでは,究極の高周波トランスとしてプリント基板技 術を用いて作成された空芯フィルム変圧器を磁気素子と して採用する。

このフィルムトランスの動作原理は高周波で導体中の 電流分布が表面へ集中する表皮効果を利用して変圧器と しても磁気的結合を維持寸る点にあるここのため, 1 次コ イルと 2 次コイルは平行に並べ,駆動周波数の増加とと もに変圧器として機能するように設計される.Fig.1(a)は 1,2 次コイルを同心円状に並べ平面上にフィルムトラン スを構成した例である.このトランスでは外側とフィル ム中心部に 1,2 次コイルの端子を持つため,形状は平面的 でも配線が立体的となる 1,2 次コイルの端子をフィル ムの外側へ出すため,Fig.1(b) に示すようにフィルム変 圧器の表面と逆パターンで 1，2 次コイルを接続したフ イルム変圧器を裏面に装着し,基本ユニットのフィルム 変圧器とする.Fig. 1 で, a,d は一次コイル端子で, c,d は 二次コイル端子である.Fig. 2 は実際に試作したにフィル ムトランスの写真を示す.

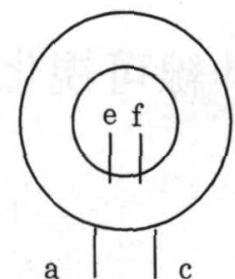

(a)

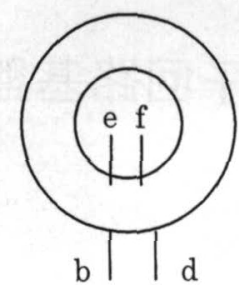

(b)
Fig.1 Principle of Film Transformer

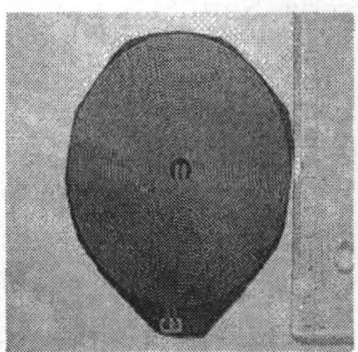

(a)Front side

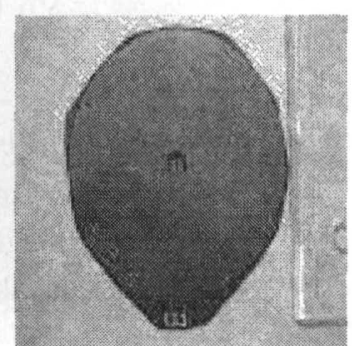

(b)Back side
Fig.2 Tested Film Transformer

\section{3 供試フライバック型 DC/DC コンバータ}

Fig.3にフライバック型DC/DC コンバータの回路を示 す.フライバック型 DC/DC コンバータの動作は Power MOS FET のソースとゲート間に小電流を通電すると, ドレインとゲート間が通電し電源 $V_{1}$ に起因する電流 $I_{1}$ が流れる.すなわち,Power MOS FET のスイッチング動 作で一次電流が流れ,この電流によってトランスの一次 コイルに磁気エネルギーが蓄えられる.Power MOS FET が OFF の区間にこの磁気エネルギーは逆極性に接 続された二次コイルを通じて負荷 $R_{L}$ へ電力を供給する. すなわち,Power MOS FET のスイッチング動作で直流 電圧が断続され,断続して流れる電流に起因して誘起す る二次電圧をダイオード D で整流して二次直流負荷電 圧が得られる。

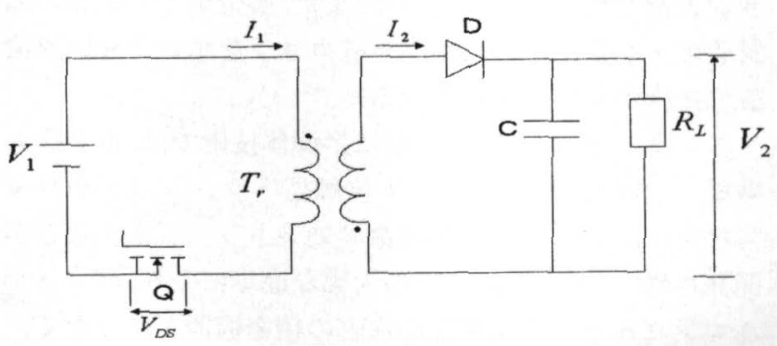

Fig.3 Circuit Diagram of Fly back Type DC/DC Converter

Fig.4に単相電源の整流回路を含めて試作した供試 $\mathrm{DC} / \mathrm{DC}$ コンバータの外観を示す.2台の DC/DC コンバー 
タを試作した.一方は単純な Fig.3に示すフライバック型 コンバータであり,他方はバイポーラトランジスタを使 ったプッシュプル型である.プッシュプル型の動作はフ ライバック型を 2 台並列にしたコンバータと考えてよ い.

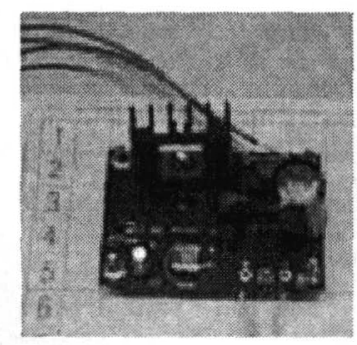

(a) Tested Converter A

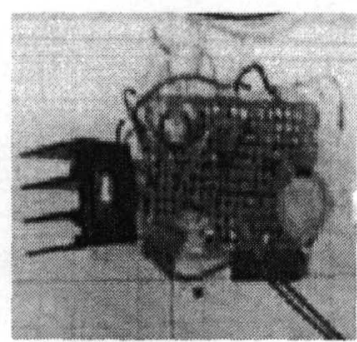

(b)Tested Converter B Fig. 4 Tested DC/DC Converters

\section{4 実験}

Fig.5 に赤外線画像の撮影法を示す.実験手順は以下の 通りである。

(1) 検査位置の確認 試験回路と赤外線カメラの位置 を確認する.

（2）電源投入 試験回路に電流を通電し，一定時間流 寸.

（3）熱画像の記録 電源を OFFにし,一定時間経過後 に回路表面の温度分布を赤外線カメラで記録す る.

(4) 評価試験回路の健全性は回路が駆動停止した後の 余熱分布評価で行う.これは, 試験回路を駆動する 電源回路の発熱が供試回路与える影響を避けるた めである.

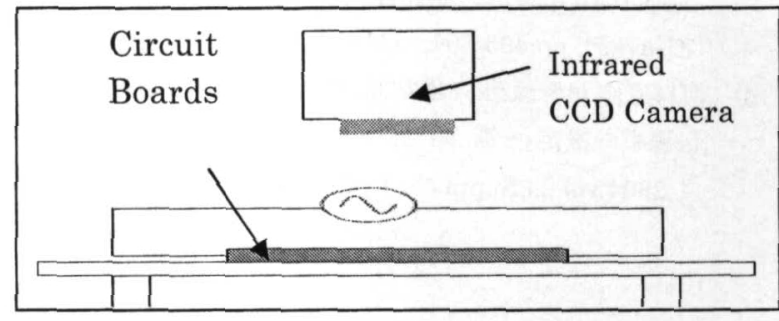

Fig.5 Schematic Diagram of Experiment

\section{5 実験結果}

Figs. 6, 7 はDC/DC コンバータへ抵抗負荷を付けて温度 が飽和点に達するまで駆動し, 駆動停止の 5 秒後に撮影 した赤外線画像である.Fig. 6(a) は供試コンバータ A が 正常に運転した場合の画像である.Fig. 6(b) は供試コン バータ B が正常に運転した場合の画像である. 何れの画 像も負荷抵抗で熱として消費されるエネルギーとスイッ チング損失を伴う Power MOS FET に熱が集中しているこ とが分かる.Fig. 6 (c) は供試コンバータ B が無負荷運転 した場合の画像である. 負荷抵抗が無限大であるため,コ ンバータ内の電流は無効電流であり, 熱損失はスイッ

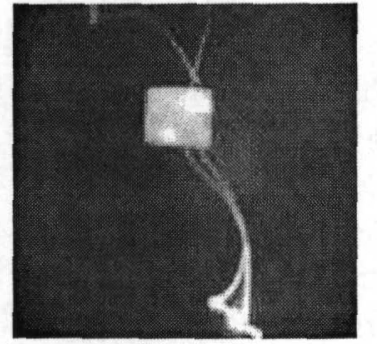

(a) Converter A at $\mathrm{t}=5$ [sec]

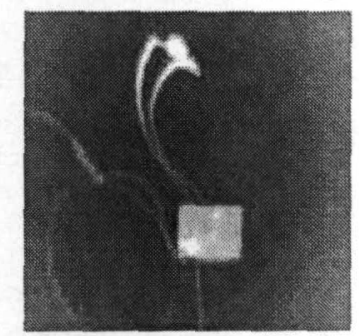

(b) Converter $\mathrm{B}$ at $\mathrm{t}=5$ [sec]

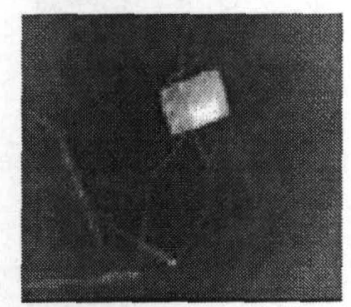

(c) Converter $\mathrm{C}$ at $\mathrm{t}=5$ [sec]

Fig. 6 Entire Infrared Images

チング損失が存在するP Power MOS FET に集中することが 分かる。

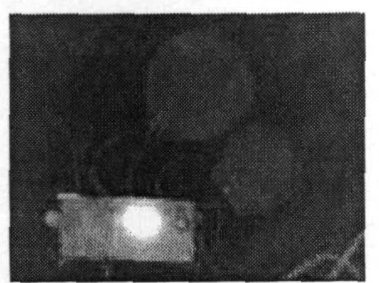

(a) Converter $\mathrm{B}$ at $\mathrm{t}=5[\mathrm{sec}]$

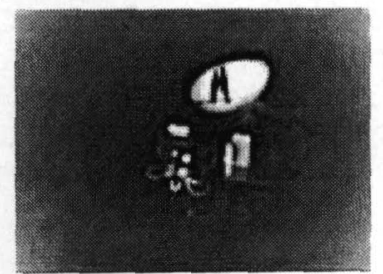

(b) Converter A at $\mathrm{t}=5$ [sec]

Fig. 7 Infrared Images focused on Film Transformers

Fig.7 はコンバータで磁気エネルギーを蓄積するフィルム トランス部分を強調して撮った赤外線画像である.Fig.7(a)は コンバータ B が正常に動作した後 5 秒後の画像であり,エネ ルギーの大部分が Power MOS FET のスイッチング損失とな 
ることが分かる.とくにフィルムトランスの励磁電流損失は小さ いことが分かる.Fig.7(b)は Power MOS FET のスイッチング が失敗し,ON 動作のままになった結果,フィルムトランスの 1 次側コイルがオーバヒートした状態を示している.

2.6 MWT による画像処理

Fig. 8 はモーダルウェーブレット変換を用いて動的熱 分布の变化部分のみを抽出して描いた画像である ${ }^{5}$.なお, これらの画像はコンバータを駆動開始してからの熱分布 の立ち上がり状態の赤外線画像から得た. 大部分の熱は 負荷抵抗へ集中しており,コンバータが正常に動作して いることが分かる.

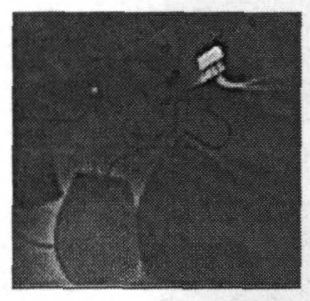

(a) Converter $\mathrm{B}$ at $\mathrm{t}=3$ [sec]

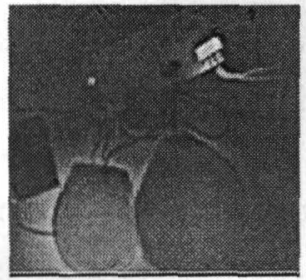

(b) Converter $\mathrm{B}$ at $\mathrm{t}=33$ [sec]

Fig.8 Dynamic Parts of Thermal Distribution Extracted by MWT

\section{3.まとめ}

本研究ではフィルムトランスを用いた超軽量・小型の スイッチング電源の開発を究極の目標としている.フィ ルムトランスを用いた DC/DC コンバータ及び電源回路 の熱分布の可視化を検討した. その結果，フィルムトラ ンスにおける励磁電流損失は少なく,スイッチング電源 の根源的問題である Power MOS FET のスイッチング 損失がコンバー夕の効率を決定することが確認された.

また、コンバータが異常動作になった場合,明確に熱分 布が異なり,容易に故障診断が可能となることが判明し た.

本来の目的である MWT の有用性を示すためには未だ データ・試料が不足している感は否めない.これを今後の 課題としたい.

\section{参考文献}

1）緑川洋一:小型・軽量磁気素子の開発とそのスイッチング 電源への応用に関する研究, 1997 年度法政大学博士論文

2) 緑川洋一: 高周波薄型変圧器とその応用に関する研 究, 1994 年度法政大学修士論文

3）増田則夫,緑川洋一, 斉藤兆古, 遠矢弘和:電子回路基板の電 流分布推定に関する研究,電気学会マグネティックス研究 会資料,MAG-97-128,1997.7,pp 13-18.

4) T.Doi, and et al: "Current Distribution Analysis on Printed Circuit Board,"

INVERSE PROBLEMS IN ENGINEERING MECHANICS (M.Tanaka,G.S.Dulikravich, Eds Elsevier), pp.495·501, (Mar.1998)

5）河村憲作, 早野誠治,斉藤兆古,堀井清之: 「赤外線画像から熱 伝導率の推定」,第 32 回可視化情報シンポジウム講演論 文,2004 vol.24 Suppl.No.1 p219·p226 